M. Đ. Učur*

\title{
PROCJENA RIZIKA (NA RADU), NOMOTEHNIČKE OZNAKE I PRAVNA NARAV
}

UDK 331.45:340.134

PRIMLJENO: 15.9 .2016$.

PRIHVAĆENO: 2.1 .2017

\begin{abstract}
SAŽETAK: Procjena rizika (na radu) je poseban akt poslodavca propisan Zakonom o zaštiti na radu i Pravilnikom o izradi procjene rizika.

Ima brojne posebnosti u materijalno-pravnom i nomotehničkom smislu, i to: ime (naziv) propisa, vizu za nadležnost poslodavca da ovaj akt donese; sadržaj; postupak donošenja, primjene i kontrole (od donošenja, objavljivanja i revizije). Vrelo je prava zaštite na radu. Osim toga, ima vremensko i prostorno važenje.

O njegovoj pravnoj prirodi ima neslaganja. Autor, u ovom članku, piše da je procjena rizika (na radu) autonomni opći akt (sui generis). To dokazuje njegovim oznakama na temelju učenja nomotehnike kao znanosti o izradi propisa.
\end{abstract}

Ključne riječi: procjena rizika, zaštita na radu, poslodavac, nomotehničke oznake

\section{UVOD}

Pravo zaštite na radu ima poseban predmet izučavanja i posebnu metodu stvaranja, ostvarivanja, nadzora i kontrole. U stvaranju pravnih normi koje čine pravo zaštite na radu, u objektivnom smislu sudjeluju brojni subjekti. To se odnosi i na stvaranje heteronomnih i autonomnih normi toga prava. Pri tome se moraju znati i koristiti sve objektivne i subjektivne nomotehničke pretpostavke (karakteristike) za znanstveno stvaranje novoga prava.

Autonomni propisi u pravu zaštite na radu imaju posebnu zaštitu države koja zakonima određuje njihovo ime, donosioca, sadržaj, postupak stvaranja, objavljivanja i stupanja na sna-

\footnotetext{
*Dr. sc. Marinko Đ. Učur, dipl. pravnik, sveučilišni profesor i znanstveni savjetnik (u trajnom zvanju) iz Rijeke (marinko.ucur051@ gmail.com).
}

gu. Na taj način oni postaju dio pravnog sustava u državi, vrelo su prava i mogu biti predmetom ocjene zakonitosti. Njihovo nedonošenje ili povreda objektivnih pretpostavki njihovog donošenja kvalificira se kao protupravno djelo.

To se odnosi i na procjenu rizika koju donosi poslodavac prema posebnom postupku i s posebnim sadržajem. lako, u teoriji pa i u praksi o tome ima neslaganja (drukčijih mišljenja), tvrditi je da je procjena opasnosti sui generis autonomni opći akt i vrelo prava zaštite na radu. Njihov naziv (ime) odredio je Zakon o zaštiti na radu, kao i sadržaj (minimalni, obvezni i koji se usklađuje). Ima svoje prostorno i vremensko važenje i druge nomotehničke oznake (pretpostavke, karakteristike). ${ }^{1}$

'Zakon o zaštiti na radu - N.N., br. 71/14., 118/14. i 154/14. Učur, Marinko: Nomotehnika u radnom pravu i pravu zaštite na radu, Veleučilište, Rijeka, 2007. 


\section{PRAVNI OKVIR I OSNOVA ZA IZRADU PROCJENE RIZIKA}

Pravilnikom o izradi procjene rizika propisuju se uvjeti, način i metoda izrade procjene rizika, obvezni sadržaji obuhvaćeni procjenom i podaci na kojima se procjena rizika temelji te klasifikacija opasnosti, štetnosti i napora na radu i u vezi s radom. ${ }^{2}$

Zakon o zaštiti na radu i Pravilnik o izradi procjene rizika treba tumačiti i primjenjivati tumačeći i primjenjujući brojne univerzalne norme o zaštiti na radu, prvenstveno konvencije Međunarodne organizacije rada (MOR-a, ILO), primarne i sekundarne propise Europske unije, prvenstveno direktive, zakone koje je donio Hrvatski sabor o zaštiti na radu i druge koji imaju izravnu ili neizravnu vezu s tim normama, ali i druge podzakonske (provedbene) propise koje su donijeli nadležni ministri na temelju ovlasti iz zakona, kao što su oni što reguliraju: sigurnosne znakove ${ }^{3}$; zaštitu radnika od rizika zbog izloženosti karcinogenima i/ili mutagenima ${ }^{4}$; sigurnost i zaštitu zdravlja na radu trudne radnice, radnica koje su nedavno rodile i radnice koja doji ${ }^{5}$; zaštitu radnika od rizika zbog izloženosti opasnim kemikalijama na radu ${ }^{6}$; obavljanje poslova zaštite na radu'; osposobljavanje iz zaštite na radu i polaganje stručnog ispita ${ }^{8}$; ovlaštenja za poslove zaštite na radu ${ }^{9} \mathrm{i} d r$.

Tu su i provedbeni (podzakonski) akti koje je trebalo uskladiti sa Zakonom o zaštiti na radu (2014.) o: sigurnosti i zaštiti zdravlja pri radu s računalom ${ }^{10}$; zaštiti na radu pri ručnom prenošenju tereta ${ }^{11}$; uporabi osobnih zaštitnih sredstava $^{12}$; sigurnosti i zdravlju pri uporabi radne

\footnotetext{
${ }^{2}$ Pravilnik o izradi procjene rizika - N.N., br. 112/14.

${ }^{3}$ N.N., br. 91/15., 102/15. (Pravilnik...)

${ }^{4}$ N.N., br. 91/15. (Pravilnik...)

${ }^{5}$ N.N., br. 91/15. (Pravilnik...)

${ }^{6}$ N.N., br. 91/15. (Pravilnik...)

${ }^{7}$ N.N., br. 112/14., 43/15., 72/15., 140/15. (Pravilnik...)

${ }^{8}$ N.N., br. 112/14. (Pravilnik...)

${ }^{9}$ N.N., br. 112/14., 84/15. (Pravilnik ...)

${ }^{10}$ N.N., br. 69/05. (Pravilnik...)

${ }^{11}$ N.N., br. 42/05. (Pravilnik...)

${ }^{12}$ N.N., br. 21/08. (Pravilnik...)
}

opreme $^{13}$; sigurnosti i zdravlju pri radu s električnom energijom ${ }^{14}$; najmanjim zahtjevima sigurnosti i zaštite zdravlja radnika te tehničkom nadgledanju postrojenja, opreme, instalacija i uređaja u prostorima ugroženim eksplozivnom atmosferom ${ }^{15}$; najmanjim zahtjevima za unapređenje sigurnosti i zdravlja radnika zaposlenih u naftnom rudarstvu ${ }^{16}$; zbog izlaganja azbestu ${ }^{17}$; zbog izloženosti biološkim agensima pri radu ${ }^{18}$; o biološkim graničnim vrijednostima ${ }^{19}$; zaštiti na pokretnim i privremenim gradilištima ${ }^{20}$; izloženosti buci, vibracijama ${ }^{21}$; strojevima i uređajima ${ }^{22}$; poslovima s posebnim uvjetima rada ${ }^{23}$; zaštiti na radu na mjestu rada ${ }^{24}$; prvoj pomoći na radu ${ }^{25}$; evidencijama ${ }^{26}$; zaštiti u šumarstvu ${ }^{27}$; poljoprivredi i drugi.

I "opći“ propisi o radu čine okvir i osnovu za izradu procjene rizika. Npr. na poslovima na kojima uz primjenu mjera zaštite na radu nije moguće zaštititi radnika od štetnih utjecaja može se trajanje godišnjeg odmora produljiti radniku i regulirati kolektivnim ugovorom ili pravilnikom o radu. To su poslovi (u pravilu) na kojima se staž osiguranja računa s povećanim trajanjem. Posebna zaštita odnosi se na prekovremeni rad; noćni rad; rad u smjenama; normirani rad (po učinku) i slično, što sve treba precizirati u procjeni rizika. Radno vrijeme je posebna kategorija čijim "modeliranjem" poslodavac može preventivno djelovati na zaštitu zdravlja i sigurnost na radu.

Detaljno autonomnim reguliranjem pa i procjenom rizika treba zaštititi posebno zaštićene

\footnotetext{
${ }^{13}$ N.N., br. 21/08. (Pravilnik...)

${ }^{14}$ N.N., br. 88/12. (Pravilnik...)

${ }^{15}$ N.N., br. 39/05., 106/07.

${ }^{16}$ N.N., br. 40/07. (Pravilnik...)

${ }^{17}$ N.N., br. 40/07. (Pravilnik...)

${ }^{18}$ N.N., br. 155/08. (Pravilnik...)

${ }^{19}$ N.N., br. 13/09. (Pravilnik...)

${ }^{20}$ N.N., br. 51/08. (Pravilnik...)

${ }^{21}$ N.N., br. 46/08. i 155/08. (Pravilnik...)

${ }^{22}$ N.N., br. 47/02., 114/02. (Pravilnik...)

${ }^{23}$ N.N., br. 5/84. (Pravilnik...)

${ }^{24}$ N.N., br. 29/13. (Pravilnik...)

${ }^{25}$ N.N., br. 56/83. (Pravilnik...)

${ }^{26}$ N.N., br. 52/84. (Pravilnik...)

${ }^{27}$ N.N., br. 10/86. i dr. (Pravilnik...)
} 
kategorije: žene (općenito), žene trudnice, žene koje su nedavno rodile, žene koje doje; mladež, radnike - invalide i one sa smanjenim radnim sposobnostima; starije radnike; radnike koji su pretrpjeli ozljedu na radu, profesionalnu bolest ili druge bolesti u vezi s radom. To se odnosi na sve rizike rada (npr. radno vrijeme s obzirom na trajanje i raspored i dr.). To je „„̌iva“ primjenjiva i promjenjiva kategorija pa zbog toga to treba "ažurirati“ i u procjeni rizika. Brojni su podaci koji se prikupljaju kod npr. izrade analize radnih uvjeta. ${ }^{28}$ To važi i za utvrđivanje povećane plaće jer kriteriji iz procjene rizika su osnova i za primjenu toga povećanja. ${ }^{29}$

\section{Procjena rizika na radu u Zakonu o zaštiti na radu}

Zakon o zaštiti na radu u brojnim odredbama uređuje procjenu rizika na radu (članak 18 . i dr.). Iz njih "iščitavamo" ove oznake procjene rizika:

1. To je obveza poslodavca;

2. Rizici se procjenjuju onako kako utječu na život i zdravlje radnika i osoba na radu (ove subjekte radnike i osobe na radu treba istaknuti, jer i to je jedan od "atributa" određivanja procjene rizika kao općeg akta). Radnik je subjekt koji je poslodavcu uvijek poznat, određen i o njemu poslodavac vodi propisane evidencije. Osoba na radu je fizička osoba koja nije u radnom odnosu kod tog poslodavca, ali za njega obavlja određene aktivnosti, odnosno poslove (osoba na stručnom osposobljavanju za rad; osoba na sezonskom radu za obavljanje privremenih, odnosno povremenih sezonskih poslova u poljoprivredi; osoba koja radi na određenim poslovima u skladu s posebnim propisom; redoviti student i redoviti učenik srednjoškolske ustanove na radu u skladu s posebnim propisom; osoba koja radi kao volonter, naučnik,

\footnotetext{
${ }^{28}$ Europska socijalna povelja (članak 2.), N.N., br. 15/02. i 8/03.

${ }^{29}$ Šokčević, Svjetlana: Zaštita zdravlja i sigurnost na radu, TIM PRESS, Zagreb, 2006., str. 40.
}

student i učenik na praksi; osoba koja radi u vrijeme izdržavanja kazne zatvora ili odgojne mjere i slično); (čl. 3., st. 1., t. 10. Zakona o zaštiti na radu);

3. Objektivno se procjenjuju poslovi i njihova priroda osobito u odnosu na sredstva rada, radni okoliš, tehnologija, fizikalne štetnosti, kemikalije, odnosno biološke agense koje koristi, uređenja mjesta rada, organizacija procesa rada, jednoličnost rada, statodinamičke i psihofiziološke napore, rad s nametnutim ritmom; rad po učinku u određenom vremenu (normirani rad), noćni rad, psihičko radno opterećenje i druge rizike koji su prisutni, radi sprečavanja ili smanjenja rizika (čl. 18., st. 1. Zakona o zaštiti na radu);

4. Izrađuje se u pisanom ili elektroničkom obliku;

5. Mora biti dostupna radniku na mjestu rada;

6. Poslodavac primjenjuje tom procjenom navedena pravila zaštite na radu, preventivne mjere, organiziranje i provođenje radnih i proizvodnih postupaka, odnosno metoda i poduzimanje drugih aktivnosti za sprečavanje i smanjenje izloženosti radnika utvrđenim rizicima;

7. Svaki propis (odnosno njegov donosilac) ima svoj cilj (casus). Cilj procjene rizika je „otklanjanje ili svođenje na najmanju moguću mjeru vjerojatnosti nastanka ozljede na radu, profesionalnih bolesti ili bolesti u vezi s radom te kako bi na svim stupnjevima organizacije rada i upravljanja osigurao bolju razinu zaštite na radu";

8. "Neadekvatna rješenja“ u procjeni rizika ne oslobađaju poslodavca "odgovornosti u vezi sa zaštitom na radu";

9. U donošenju („postupak procjene rizika“) poslodavac mora „uključiti radnike i njihove predstavnike", i to "na način propisan ovim Zakonom" (analogne odredbe zakona kojima je reguliran postupak donošenja pravilnika o radu);

10. "Uvjete, način i metode izrade procjene, sadržaj klasifikacija opasnosti, štetnosti i 
napora u radu i u vezi s radom" propisuje ministar (nadležan za rad) pravilnikom (čl. 18., st. 6. Zakona o zaštiti na radu).

Zakon o zaštiti na radu propisuje „opća načela sprječavanja rizika na radu“ (čl. 1., st. 3.). U odredbama članka 3. Zakona o zaštiti na radu propisuju se značenja pojmova bitnih za izradu procjene rizika (kao i za primjenu drugih odredbi u sadržaju Zakona): biološke štetnosti; eksplozivna atmosfera; statodinamički, psihofiziološki napori, zatim napori vida i napori govora („koji mogu uzrokovati oštećenja zdravlja radnika koji su im izloženi"); opasne kemikalije; radna oprema; radni okoliš; sredstva rada; stres na radu; štetnosti (kemijska, biološka i fiziološka) i dr. ${ }^{30}$

Za izradu procjene opasnosti bitno je značenje pojma "rizik" u čl. 3., st. 1., t. 24. Zakona o radu: „Rizik je umnožak vjerojatnosti nastanka opasnog ili štetnog događaja i štetnosti toga događaja, odnosno njegove posljedice".

Ovo se još detaljnije vidi iz provedbenih (podzakonskih) akata (pravilnika) uz Zakon o zaštiti na radu, o: ručnom prenošenju tereta; uporabi radne opreme; izloženosti opasnim tvarima pri radu; vibracijama pri radu; strojevima i uređajima s povećanim opasnostima; poslovima s posebnim uvjetima rada; prvoj pomoći; zaštiti na radu u šumarstvu; zaštiti na radu pri utovaru i istovaru tereta; zaštiti na radu u poljoprivredi i drugi. ${ }^{31}$

Pri tome se mora voditi računa o posebnim propisima koji se odnose na oružane snage $\mathrm{RH}$; policijske poslove i poslove zaštite i spašavanja; poslove zaštite osoba i imovine te poslove vatrogasaca i pirotehničara. ${ }^{32}$

"Život, zdravlje i očuvanje radne sposobnosti vrednote su od posebnog društvenog interesa u Republici Hrvatskoj". ${ }^{33}$

${ }^{30}$ Zavalić, Marija: Psihosocijalni rizici i zdravlje radnika, Sigurnost, br. 3/15., str. 211.

${ }^{31}$ Zakon o zaštiti na radu - cit.: čl. 103. i čl. 17., st. 7.

${ }^{32}$ Isto - čl. 4., st. 2. i 3

${ }^{33}$ Isto - čl. 5., st. 1.
Procjenjivanje rizika je jedno od općih načela prevencije u zaštiti na radu. ${ }^{34}$ Pri procjeni rizika moraju se uvažavati zahtjevi kojima mora udovoljavati sredstvo rada "kada je u uporabi“, a te zahtjeve propisuju osnovna pravila zaštite na radu. Iza njih slijede posebna pravila zaštite na radu „koja se odnose na radnike, način obavljanja poslova i radne postupke". To se odnosi i na priznata pravila zaštite na radu (norme, pravila struke ili "u praksi provjerene načine").

U odredbama o odgovornosti poslodavca za organiziranje i provođenje zaštite na radu, Zakon o zaštiti na radu, poziva se i na propise "donesena na temelju“ toga Zakona. Poslodavac je obvezan utvrditi i obavljati poslove zaštite na radu u skladu s procjenom rizika... (članak 20., st. 1. Zakona o zaštiti na radu). Bez obzira kako je poslodavac organizirao obavljanje poslova zaštite na radu, poslovi te zaštite su, pored drugih, „sudjelovanje u postupku izrade procjene rizika" koje obavlja poslodavac, stručnjak zaštite na radu, odnosno ovlaštena osoba. ${ }^{35}$

U odredbama o osposobljavanju za rad na siguran način Zakon o zaštiti na radu, pored drugih, propisuje obvezu poslodavcu da "na temelju procjene rizika, osposobi radnika za rad na siguran način..." te da radniku "objasni i da ovaj primijeni te mjere u skladu s procjenom rizika..." ${ }^{\prime \prime 36}$

Osposobljavanje se „obvezno provodi... u slučaju promjene odnosno pojave novih rizika, neovisno o tome je li s tim u vezi već izmijenio ili dopunio procjenu rizika" (čl. 27., st. 3. Zakona o zaštiti na radu). Pored radnika obvezno osposobljavanje odnosi se i na poslodavca i njegovog ovlaštenika (a „moraju se stručno usavršavati iz područja zaštite na radu“) u skladu s procjenom rizika.

Procjenom rizika preciziraju se poslovi obavještavanja radnika, povjerenika radnika, struč-

\footnotetext{
${ }^{34}$ Isto - čl. 11., st. 1., t. 2.

${ }^{35}$ Isto - čl. 21., st. 3.

${ }^{36}$ Isto - čl. 27., st. 2.
} 
njaka za zaštitu na radu, ovlaštene osobe o: rizicima vezanim za mjesto rada; mjerama; pisanim uputama; uporabi osobnih zaštitnih sredstava; dostupnosti odgovarajuće dokumentacije (kao npr. procjene rizika i dr.), što se odnosi i na savjetovanje s povjerenikom radnika; izradi procjene rizika te izmjenama, odnosno dopunama procjene rizika.

Odbor za zaštitu na radu „planira i nadzire promjene pravila zaštite na radu kod poslodavca" (u što neposredno ulazi i procjena rizika).

„... Poslodavac je obvezan u procjeni rizika naznačiti poslove koji su potencijalno rizični za posebno osjetljive skupine radnika..." (maloljetni radnici, trudne radnice, radnice koje su nedavno rodila, radnice koje doje; radnici oboljeli od profesionalne bolesti te radnici kod kojih je utvrđena smanjena i prestala radna sposobnost....); (članak 37. Zakona o zaštiti na radu). $\mathrm{Na}$ temelju procjene rizika poslodavac provodi posebnu zaštitu navedenih skupina radnika. U procjeni rizika posebno se utvrđuje obveza poslodavca u vezi sa sredstvima rada, osobnom zaštitnom opremom i mjestima rada; u vezi s tehnologijama rada i radnim postupcima; $\mathrm{u}$ vezi $\mathrm{s}$ ispitivanjem radnog okoliša (izloženost radnika fizikalnim, kemijskim i biološkim štetnostima na radu...).

To se odnosi i na obveze poslodavca u vezi s uporabom opasnih kemikalija na radu, u skladu s procjenom rizika... i u vezi s uporabom bioloških agensa na radu (čl. 46.-50. Zakona o zaštiti na radu), te sigurnosne znakove, pisane obavijesti i upute (čl. 53. istog Zakona).

Poslodavac provodi mjere zaštite na radu u skladu s pravilima zaštite na radu i posebnim propisima "na mjestima rada ugroženim eksplozivnom atmosferom" (čl. 55., st. 7. Zakona o zaštiti na radu).

Procjenom rizika utvrđuje se visina koncentracije alkohola koja je dopuštena (čl. 58., st. 3. Zakona o zaštiti na radu).

Zakon propisuje obvezu poslodavca da postavlja sigurnosne i druge znakove, a radniku učini dostupnim procjenu rizika za mjesto rada i poslove koji se na njemu obavljaju, te rokove dostupnosti procjene rizika radnicima (čl. 62. Zakona o zaštiti na radu).

Preko povjerenika radnika za zaštitu na radu da sudjeluje u postupku izrade procjene rizika i njezine primjene obveza poslodavca je da mu to omogući uz propisanu zaštitu (čl. 70.-72. Zakona o zaštiti na radu).

Posebne obveze ima koordinator za zaštitu na radu u koordiniranju pravila zaštite na radu prilikom izrade izvedbenog projekta (čl. 77. Zakona o zaštiti na radu).

Mnogostruki poslovi i funkcije medicine rada proizlaze iz procjene rizika (članak 81. Zakona o zaštiti na radu). Pored drugih, osoba ovlaštena za zaštitu na radu kod poslodavca može biti ovlaštena za izradu procjene rizika (čl. 82., st. 3. toga Zakona).

Složena pitanja i odnose u primjeni Zakona o zaštiti na radu nadzire (provodi upravni nadzor) središnje tijelo državne uprave nadležno za poslove rada (primjena Zakona, podzakonskih akata i drugih propisa zaštite na radu); (članak 89. Zakona o zaštiti na radu).

Inspekcijski nadzor obavlja središnje tijelo nadležno za poslove inspekcije rada, a u drugim djelatnostima druga središnja tijela, u skladu s posebnim propisima. U postupku inspekcijskog nadzora inspektor „usmenim rješenjem poslodavcu naređuje izradu procjene rizika" (članak 92. Zakona o zaštiti na radu).

U prekršajnim odredbama Zakon o zaštiti na radu propisuje novčanu kaznu od 30.000,00 kuna za poslodavca (pravnu osobu) ako nema izrađenu procjenu rizika... u pisanom ili elektroničkom obliku, ili ako izrađena procjena rizika ne odgovara postojećim rizicima na radu i u vezi s radom, ili nije dostupna radniku na mjestu rada (čl. 98., st. 1., t. 1. u vezi sa čl. 18., st. 2.). Za taj prekršaj kažnjava se poslodavac fizička osoba i odgovorna osoba u pravnoj osobi sa 6.000,00 kuna. 
U „Prijelaznim i završnim odredbama” propisan je način i rok prestanka važenja „izrađenih procjena opasnosti i osposobljavanja za rad na siguran način..." prema Zakonu o zaštiti na radu N.N., br. 59/96. do 143/12. (čl. 101., st. 5. Zakona o zaštiti na radu). ${ }^{37}$

\section{Pravilnik o izradi procjene rizika}

U Narodnim novinama, broj 112 od 24.9.2014. objavljen je Pravilnik o izradi procjene rizika (dalje: Pravilnik).

"Ovim Pravilnikom se propisuju uvjeti, način i metoda izrade procjene rizika, obvezni sadržaji obuhvaćeni procjenom i podaci na kojima se procjena rizika temelji te klasifikacija opasnosti, štetnosti i napora na radu i u vezi s radom". ${ }^{38}$

Pravilnik je podzakonski akt (provedbeni propis) donesen od ministra nadležnog za rad, pozivom na odredbe čl. 18., st. 6. Zakona o zaštiti na radu (dalje: Zakon ili ZZR). ${ }^{39}$

„Rizik je umnožak vjerojatnosti nastanka opasnog ili štetnog događaja i štetnosti toga događaja, odnosno njegove posljedice" ${ }^{40}$ Poslodavac je dužan uzeti u obzir „poslove i njihovu prirodu" i procjenjivati rizike "za život i zdravlje radnika i osoba na radu". To obuhvaća „Osobito u odnosu na sredstva rada, radni okoliš, tehnologiju, fizikalne štetnosti, kemikalije, odnosno biološke agense koje koristi, uređenje mjesta rada, organizaciju procesa rada, jednoličnost rada, statodinamičke i psihofiziološke napore, rad s nametnutim ritmom, rad po učinku u određenom vremenu (normirani rad), noćni rad, psihičko radno opterećenje i druge rizike koji su prisutni, radi sprječavanja ili smanjenja rizika". ${ }^{41}$

\footnotetext{
${ }^{37}$ Inspekcijske poslove u području zaštite na radu obavlja inspektor rada, kao upravna organizacija u sastavu Ministarstva rada i mirovinskoga sustava. Inspekcijske poslove obavlja inspekcijskim nadzorom provedbe Zakona i drugih propisa kojima se uređuje zaštita na radu (čl. 2. i 3. Zakona o Inspektoratu rada - N.N., br. 19/14.).

${ }^{38}$ Pravilnik o izradi procjene rizika - N.N., br. 112/14., članak 1., st. 2. (stupio na snagu 3.10.2014.).

${ }^{39}$ Zakon o zaštiti na radu - N.N., br. 71/14.: članak 18., st. 6.

${ }^{40}$ ZZR: članak 3., st. 1., t. 24.

${ }^{41}$ Isto: članak 18., st. 1.
}

„Opasnosti su svi uvjeti na radu i u vezi s radom, koji mogu ugroziti sigurnost i zdravlje radnika". ${ }^{42}$

Subjekti koje posebno navodi (određuje) ovaj Pravilnik su: poslodavac, radnik, osobe ovlaštene za izradu procjene rizika; osobe na radu; ovlašteni odgovorni za provedbu mjera; trudnica; osobe koje su rodile; osobe koje doje; Zavod za unapređivanje zaštite na radu; predstavnici radnika; ovlaštenici poslodavaca, stručnjaci zaštite na radu; stručnjaci iz pojedinih područja; odbor zaštite na radu.

Procjena rizika je autonomni opći akt poslodavca: ima svoga donositelja, vizu (pravnu osnovu), ime, prostorno i vremensko važenje, propisani postupak donošenja i sadržaj. Što je djelatnost poslodavca složenija, heterogenost i broj radnika veći, vjerojatnosti nastanka rizika i posljedice, opasnosti, štetnosti i napori na radu i u vezi s radom brojnije, to je postupak izrade procjene rizika složeniji, a sadržaj toga akta zahtjevniji.

\section{Obveza procjene rizika na radu}

„Poslodavac je obvezan... procjenjivati rizik za život i zdravlje radnika i osoba na radu..."43

Procjena rizika je elaborat, izvedbeni projekt, akt-propis autonomnog karaktera „u pisanom ili elektroničkom obliku“.

Procjena rizika mora bit aktualna... „koja odgovara postojećim rizicima na radu i u vezi s radom..."

Procjena rizika je „dostupna radniku na mjestu rada", jer je riječ o procjeni rizika za život i zdravlje radnika i osoba na radu. ${ }^{44}$

„Mjesto rada je svako mjesto na kojemu radnici i osobe na radu moraju biti, ili na koje moraju ići, ili kojemu imaju pristup tijekom rada zbog poslova koje obavljaju za poslodavca, kao i svaki prostor, odnosno prostorija koju posloda-

\footnotetext{
${ }^{42}$ Isto: članak 3., st. 1., t. 9.

${ }^{43}$ Isto: članak 18., st. 1.

${ }^{44}$ Isto: članak 18., st. 2.
} 
vac koristi za obavljanje poslova i koja je pod njegovim izravnim ili neizravnim nadzorom. ${ }^{45}$

$\mathrm{Na}$ temelju procjene rizika primjenjuju se pravila zaštite na radu (osnovna pravila zaštite na radu, posebna pravila zaštite na radu, priznata pravila zaštite na radu). Procjena rizika je "izvedbeni projekt". Na osnovi procjene rizika poslodavac: primjenjuje preventivne mjere („prevencija je planirana, odnosno poduzeta mjera u svakom radnom postupku kod poslodavca s ciljem sprečavanja ili smanjenja rizika na radu"); organizira i provodi radne i proizvodne postupke, odnosno metode); poduzima druge aktivnosti za sprečavanje i smanjenje izloženosti radnika utvrđenim rizicima. Cilj je „kako bi poslodavac otklonio i sveo na najmanju moguću mjeru vjerojatnost nastanka ozljede na radu, oboljenja od profesionalne bolesti ili bolesti u vezi s radom te kako bi na svim stupnjevima organizacije rada i upravljanja osigurao bolju razinu zaštite na radu". ${ }^{46}$

Pretpostavka je dobra organizacija rada na svim razinama, uočavanje nastanka opasnog i štetnog događaja na radu i u vezi s radom, procjena štetnosti događaja, odnosno procjenjivanja njegove štetne posljedice i drugo. ${ }^{47}$

„Propusti učinjeni u postupku procjene rizika... ne oslobađaju poslodavca obveza i odgovornosti u vezi sa zaštitom na radu. ${ }^{48}$

Kako je već istaknuto, elaborat o procjeni rizika nije statična kategorija, dokument odnosno akt. On se treba mijenjati odnosno dopunjavati dok dođe do bitnih promjena u poslovima i njihovoj prirodi i rizicima za život i zdravlje radnika i osoba na radu kod određenog poslodavca. Zbog toga i jesu predviđene izmjene i dopune procjene rizika. „Procjena rizika mora odgovarati postojećim opasnostima, štetnostima odnosno naporima. ${ }^{49}$

\footnotetext{
${ }^{45}$ Isto: članak 3., st. $1 .$, t. 5.

${ }^{46}$ Isto: članak 18., st. 3.

${ }^{47}$ Štetne posljedice su od bioloških štetnosti, eksplozivne atmosfere, napora, opasnih kemikalija, poslova s posebnim uvjetima rada, sredstava rada, kemijskih i fizikalnih štetnosti i dr. ZZR: članak 3., st. 1.

${ }^{48}$ Isto: članak 18., st. 4.

${ }^{49}$ Pravilnik - cit. članak 3., st. 2.
}

„Poslodavac je obvezan radnike i njihove predstavnike uključiti u postupak procjene rizika na način propisan ovim Zakonom". ${ }^{50}$ To se misli na zborove radnika (skupove), predstavnike radnika, radničke sindikate, radnička vijeća i dr., a posebno putem odbora zaštite na radu „koji prihvaća procjenu rizika ili predlaže ispravke te daje primjedbe i prijedloge" ${ }^{.51}$

„Procjenu rizika mogu izrađivati osobe ovlaštene za izradu procjene rizika. Procjenu rizika za vlastite potrebe može izrađivati poslodavac". ${ }^{52}$ Dakako, to će moći raditi samo oni poslodavci koji imaju „ekipe“ (timove) u sklopu svoje djelatnosti koji će moći zadovoljiti zahtjevima postupka procjenjivanja rizika (razina opasnosti, štetnosti i napora u smislu nastanka ozljede na radu, profesionalne bolesti, bolesti u vezi s radom te poremećaja u procesu rada koji bi mogao izazvati štetne posljedice za sigurnost i zdravlje radnika). ${ }^{53}$

\section{Obvezni sadržaj obuhvaćen procjenom rizika}

„Procjena rizika je postupak koji provodi poslodavac za sve poslove" (čl. 1., st. 3. Pravilnika). U odredbama članka 4. Pravilnik propisuje obvezu poslodavcu da mora „imati izrađenu procjenu rizika za sve poslove koje za njega obavljaju radnici i osobe na radu".

Sastavni dio Pravilnika je Matrica procjene rizika prema općim kriterijima rizika (vjerojatnost, posljedica). Element „vjerojatnost“ ima tri stupnja (oznake): malo vjerojatno („ne bi se trebalo dogoditi tijekom cijele profesionalne karijere radnika“); vjerojatno („može se dogoditi samo nekoliko puta tijekom profesionalne karijere radnika“) i vrlo vjerojatno („može se ponavljati tijekom profesionalne karijere radnika"). Kriterij „posljedica“ (veličina posljedica - štetnosti) ima tri stupnja: „malo štetno" (ozljede i bolesti koje ne uzrokuju produženu bol, npr. male ogrebotine, iritacije oka, glavobolje itd.); "srednje štetno“

\footnotetext{
${ }^{50}$ ZZR: cit. članak 18., st. 5.

${ }^{51}$ Pravilnik - cit. članak 12., st. 2.

${ }^{52}$ Isto: članak 3.

${ }^{53}$ Isto: članak 2.
} 
(ozljede i bolesti koje uzrokuju umjerenu, ali produženu bol ili bol koja se povremeno ponavlja, npr. rane, manji prijelomi, opekline drugog stupnja na ograničenom dijelu tijela, dermatološke alergije itd.); „izrazito štetno“ (ozljede i bolesti koje uzrokuju tešku i stalnu bol i/ili smrt, npr. amputacije, komplicirani prijelomi, razne opekline drugog ili trećeg stupnja na velikom dijelu tijela itd.).

Matrica procjene rizika ima elemente: „,vjerojatnosti“ („malo vjerojatno", „vjerojatno" i "vrlo vjerojatno"), te uz te "vjerojatnosti" "veličina posljedica štetnosti“: "malo štetno" (i mali rizik i srednji rizik); "srednje štetno" (mali rizik, srednji rizik i veliki rizik); te "izrazito štetno" (sve veći rizik, veliki rizik). ${ }^{54}$

U "Prilogu II" Pravilnik utvrđuje „primjer poslova s malim rizicima“. Prvenstveno se radi o administrativnim, uredskim poslovima, pomoćnim uslugama, trgovina električnom energijom i drugim trgovinama bez skladištenja, savjetovanja, poslovi agenata, poslovi prikazivanja filmova, računovodstveni poslovi, umjetnički i zabavni poslovi, poslovi knjižnica i arhiva, muzeja, poslovi organizacije poslodavca i strukovnih članskih organizacija i sl. ${ }^{55}$

U „Prilogu III" nalazi se „klasifikacija opasnosti, štetnosti i napora na radu i u vezi s radom".

"Opasnosti“ se klasificiraju na: „mehaničke opasnosti" (alati, strojevi i oprema, sredstva za horizontalni prijenos; sredstva za vertikalni prijenos; rukovanje predmetima i ostale mehaničke opasnosti); "opasnosti od padova" (pad radnika i drugih osoba i pad predmeta); "električna struja“; "požar i eksplozija“; "tehničke opasnosti“.

„Štetnosti“ se klasificiraju na: „kemijske štetnosti" (otrovi, korozivi, nadražljivci, zagušljivci, senzibilizatori, fibrogeni, mutageni, karcinogeni, teratogeni); "biološke štetnosti“ (zarazni materijal, opasne životinje i dr.); "fizikalne štetnosti" (buka, vibracije, promijenjeni tlak, nepovoljni

${ }^{54}$ Pravilnik - cit.: „Prilog I“

${ }^{55}$ Pravilnik - cit.: "Prilog II" klimatski i mikroklimatski uvjeti, ionizirajuće zračenje, osvijetljenost i dr.).

"Napori" mogu biti: „statodinamički", "psihofiziološki“ ",napori vida“ $i$ "napori govora". ${ }^{56}$

„Obvezni prilozi uz procjenu rizika su: 1) sigurnosni podaci izvora fizikalne štetnosti, kemikalija, odnosno bioloških agensa koji se upotrebljavaju; 2) popis radne opreme koja se upotrebljava pri obavljanju poslova; 3) popis osobne zaštitne opreme za poslove kod kojih se mora upotrebljavati; 4) popis potrebnih ispitivanja; 5) popis poslova s posebnim uvjetima rada". ${ }^{57}$

\section{Način i metoda izrade procjene rizika}

Pravilnikom se propisuje način i metoda izrade procjene rizika. Radi se o "minimalnim zahtjevima ... ali ne utječe na primjenu drugih priznatih načina i metoda procjene rizika nakon što su ispunjeni propisani minimalni zahtjevi“. ${ }^{58}$

Procjena rizika je postupak „a sastoji se od: 1) prikupljanja podataka na mjestu rada; 2) analize i procjene prikupljenih podataka (što uključuje: utvrđivanje opasnosti, štetnosti i napora, procjenjivanje opasnosti, štetnosti i napora, utvrđivanje mjere za otklanjanje odnosno smanjivanje opasnosti, štetnosti odnosno napora); 3) plana mjera za uklanjanje odnosno smanjivanje razine opasnosti, štetnosti i napora (koji mora sadržavati: rokove, ovlaštenike odgovorne za provedbu mjera te način kontrole nad provedbom mjera); 4) dokumentiranja procjene rizika". ${ }^{59}$

„Prikupljanje podataka uključuje: 1) poslove koji se obavljaju na mjestu rada; 2) broj radnika koji obavljaju te poslove; 3) mjesta rada gdje se poslovi obavljaju; 4) uređenje mjesta rada; 5) popis radne opreme; 6) popis izvora fizikalnih, kemijskih i bioloških štetnosti i 7) organizaciju rada i raspored radnog vremena". ${ }^{60}$ "Procjenjivanje rizika se provodi uz aktivno sudjelovanje

\footnotetext{
${ }^{56}$ Pravilnik - cit.: „Prilog III"

${ }^{57}$ Pravilnik - cit.: članak 11.

${ }^{58}$ Isto: članak 1., st. 1. i 2.

${ }^{59}$ Isto: članak 5.

${ }^{60}$ Isto: članak 6., st. 2.
} 
radnika koji obavljaju poslove i uvažavanje njihovih stavova“, pri čemu se „moraju uvažiti provedbeni propisi iz zaštite na radu..." ${ }^{161}$

„Poslodavac je obvezan na temelju procjene rizika primjenjivati pravila, mjere, postupke i aktivnosti za sprječavanje i smanjivanje rizika te osiguravati višu razinu zaštite na radu" ${ }^{62}$

Svaki akt, svaki projekt pa i Procjena rizika treba sadržavati postupak njegove provedbe. Taj postupak čine rokovi, organi (tijela) i radnje. „Poslodavac mora odrediti rokove, ovlaštenike za provedbu te način kontrole nad provedbom mjera" za sprečavanje i smanjivanje rizika. ${ }^{63}$

Izrada procjene rizika je obveza svakog poslodavca. Bez procjene rizika nema adekvatne primjene pravnih pravila o zaštiti na radu. Bez toga "elaborata”, „projekta" ne mogu se izrađivati i primjenjivati autonomni opći akti i drugi akti kod poslodavca. Na temelju procjene rizika poslodavac donosi pravilnik o zaštiti na radu, odluke, upute i dr. i utvrđuje organizaciju zaštite na radu. To je uvijek pisani akt koji se mora ažurirati. Procjena rizika ima tekstualni i grafički dio. Svi troškovi izrade procjene rizika terete poslodavca.

\section{NOMOTEHNIČKE KARAKTERISTIKE PROCJENE RIZIKA}

Procjena rizika je polazište za organiziranje i uređivanje te provođenje zaštite na radu kod poslodavca. Sadržaj je opisan: postojanje (opasnosti) rizika i njihova identifikacija; vrste opasnosti; opseg opasnosti; analiza rizika; mjere za otklanjanje rizika i kontrola provođenja. Procjena rizika omogućava da se zaštita na radu kod poslodavca cjelovitije provodi kao skup tehničkih, zdravstvenih, pravnih, psiholoških, pedagoških, andragoških i drugih djelatnosti pomoću kojih se

\footnotetext{
${ }^{61}$ Isto: članak 7., st. 2. i 3.

${ }^{62}$ Isto: članak 7., st. 4. i članak 8., st. 1. „Poslovi s velikim rizicima su, između ostalog, utvrđeni posebnim propisom o poslovima s posebnim uvjetima rada" (članak 8., st. 3. Pravilnika).

${ }^{63}$ Isto: članak 9.
}

otklanjaju rizici što ugrožavaju život i zdravlje osobe na radu i utvrđuju mjere, postupci i pravila da bi se otklonile ili smanjile te opasnosti odnosno rizici.

\section{Viza - pravna osnova za izradu procjene rizika}

Viza ovog akta je u odredbama Zakona o zaštiti na radu. Procjena rizika je „viza“ za autonomno uređivanje pravila zaštite na radu. To je akt (elaborat) koji može biti u pisanom ili elektroničkom obliku.

\section{Pravna narav procjene rizika}

Procjena rizika je opći akt. Sadrži opće norme koje obvezuju svakoga tko se nađe u prostoru, prostorijama i radnom okolišu poslodavca. Donosi se po posebnom postupku. Procjena opasnosti ima: svoje ime (naziv akta); sadržaj; postupak izrade i snagu propisa, posebno vremensko važenje.

\section{Subjekti u procjeni rizika}

Subjekti u procjeni rizika su: poslodavac, stručni tim za izradu; radnici; povjerenici i ovlaštenici; odbor za zaštitu na radu; radničko vijeće odnosno sindikat; inspektor rada i drugi.

Posebnu ulogu imaju članovi stručnog tima koji izrađuju procjenu. Oni su u nomotehničkom smislu redaktori. Rade timski od prikupljanja "građe" do konačne izrade. Paze na sadržaj: opći podaci (o poslodavcu, objektima); postojeće stanje zaštite (u cjelini, po ustrojbenim jedinicama, radnim mjestima); analiza i procjena prikupljenih podataka; Posebni dio; Plan mjera; prilozi i dr.

\section{Pretpostavke za izradu procjene rizika}

Nomotehnika uči da se pretpostavke za izradu propisa dijele na objektivne i subjektivne. Objektivne nomotehničke pretpostavke za izradu (propisa) procjene rizika su: nadležnost; postupak; sadržaj; prostorno i vremensko djelovanje procjene rizika. 
Subjektivne nomotehničke pretpostavke za izradu procjene rizika su: pravna svijest; znanje (opća znanja, znanje nomotehničkog, jezičnog, logičkog i pravnog izražavanja); znanje pravnog sustava; znanje moderijalnog prava (prvenstveno radnog prava i prava zaštite na radu); priprema gradiva i timski rad.

\section{ZAKLJUČAK}

Iz ovog rada proizlaze sljedeći zaključci:

1. Brojni su propisi, heteronomnog i autonomnog karaktera u pravu zaštite na radu. Pravne norme u tim odnosima pored brojnosti su posebne (specifične), kogentne pa i striktne. Obuhvaćaju poslodavce i radnike, kao i druge osobe na radu, ali i druge subjekte koji sudjeluju u stvaranju, primjeni i kontroli tih normi.

2. Sve karakteristike autonomnog općeg akta ima i procjena rizika (na radu) koja čini predmet ovoga rada. Obveza poslodavca da donese procjenu rizika propisana je Zakonom o zaštiti na radu i Pravilnikom o izradi procjene rizika. Na taj način uređeni su: viza (pravna osnova), donositelj, sadržaj, postupak, prostorno i vremensko važenje procjene rizika. Za izradu procjene rizika potrebno je ispuniti i subjektivne nomotehničke pretpostavke.

\section{RISK ASSESSMENT (AT WORK), NOMOTECHNICS AND LEGAL CHARACTER}

SUMMARY: Risk assessment (at work) is a special document drafted by employers as the method of implementation of the Safety at Work Act and the Regulations on Risk Assessment Drafting. The document contains numerous material, legal and nomotechnical features, such as: name of regulation, certificate of competence entitling the employer to draft the document, content, procedure, implementation and control (from passing, to publication and revision). It is the source document guaranteeing the right to safety at work. Furthermore, it is limited in time and space. There are disputes as to its legal nature. In this paper the author argues that risk assessment (at work) is an autonomous general document (sui generis). The author supplies proof of this using nomotechnics.

Key words: risk assessment, occupational safety, employer, nomotechnics 